\title{
Pemanfaatan Bahan Organik dalam Perbaikan Beberapa Sifat Tanah Pasir Pantai Selatan Kulon Progo
}

\author{
DOI 10.18196/pt.2015.037.31-40
}

\author{
Andi Surya Zannah Hasibuan \\ PT. PP London Sumatra, Regional Kalimantan Timur, \\ Jl. Ahmad Yani Komplek Ruko Mitra Mas 8 No. 27-28Samarinda, Kalimantan Timur, 75117, Indonesia, \\ e-mail:a.sz78@yahoo.com
}

\begin{abstract}
ABSTRAK
Penelitian tentang pemanfaatan bahan organik dalam perbaikan beberapa sifat tanah pasir Pantai Selatan Kulon Progo, dilaksanakan di rumah kaca Fakultas Pertanian Universitas Muhammadiyah Yogyakarta. Penelitian disusun dengan rancangan acak lengkap (RAL) dengan 5 perlakuan. Perlakuan tersebut adalah, $\mathrm{PO}=$ tanpa perlakuan bahan organik (kontrol), P1 = 30 ton per hektar kompos kotoran sapi, P2 = 30 ton per hektar kompos kotoran ayam, P3 = 30 ton per hektar kompos daun angsana, P4 = 30 ton per hektar kompos daun gamal, setiap perlakuan yang dipersiapkan diulang 5 kali. Hasil penelitian menunjukkan bahwa pemanfaatan bahan organik dapat meningkatkan sifat tanah pasir pantai Selatan Kulon Progo. Daun angsana merupakan sumber bahan organik terbaik dalam meningkatkan sifat fisik dan kimia tanah seperti kandungan lengas, berat volume, porositas, dan kadar C-Organik tanah.

Kata kunci : Sumber bahan organik, Tanah pasir pantai
\end{abstract}

\begin{abstract}
An experiment about the utilization of organic matter to improve some properties of sandy soils of south beach of Kulon Progo was conducted in Green House, Faculty of Agriculture, Universitas Muhammadiyah Yogyakarta. The research was carried out in experimental method which arranged in Completely Randomized Design (CRD) with 5 treatments. The treatments were PO = without compost application (Control), P1 = 30 ton per hectare of cow dung compost, $P 2$ = 30 ton per of hectare of poultry compost, $P 3=30$ ton per hectare of Angsana leaves compost, $P 4=30$ ton per hectare of gamal leaves compost, each treatment were replicated 5 times. The result showed that utilization of organic matter could improve the properties of sandy soils of south beach of Kulon Progo. Angsana leaves were the best organic matter sources in improving the physical and chemical of soil properties, such as water content, bulk density, soil porosity, and soil C-Organic content.

Keywords: Organic matter sources, Soil properties of sandy soil
\end{abstract}

\section{PENDAHULUAN}

Indonesia dikenal sebagai negara agraris, karena mempunyai areal pertanian yang sangat luas dan sebagian besar penduduknya bermata pencarian sebagai petani, akan tetapi dewasa ini lahan-lahan pertanian yang ada di Indonesia semakin sempit khususnya lahan produktif. Hal ini terjadi karena peningkatan pengembangan sektor industri yang menyebabkan alih fungsi lahan pertanian menjadi kawasan industri. Oleh karena itu, perlu dilakukan ekstensifikasi untuk memperoleh lahan pertanian baru. Salah satu peluangnya adalah pemanfaatan lahan pasir pantai. Lahan pasir pantai sangat berpotensi untuk dikembangkan menjadi lahan pertanian. Mengingat luas lahan pantai sangat luas dan belum termanfaatkan secara optimal. Badan Informasi Geospasial (BIG) dalam Gloria Samantha (2013) menyebutkan total panjang garis pantai Indonesia adalah $99.093 \mathrm{Km}$. Kawasan pantai selatan Kulon Progo dengan luas kurang lebih 2.900 hektar.

Pesisir pantai Kulon Progo sepanjang garis pantai dengan lebar $\pm 1.8 \mathrm{~km}$, terbagi dalam 4 kecamatan dan 10 desa yang mempunyai wilayah pantai dengan kondisi pesisir hampir 100\% pasir dengan kedalaman air tanah 1,5 meter sampai 3,0 meter, kawasan pantai Selatan Kulon Progo memiliki iklim ekstrem kering dengan temperatur maksimum $38^{\circ} \mathrm{C}$ dan kisaran temperatur rata-rata $32^{\circ}-36^{\circ} \mathrm{C}$, serta curah hujan tahunan 
sebesar 1.500-2.000 mm dengan vegetasi sangat jarang (Gunawan, 2009). Lahan pasir yang sangat luas mendominasi hampir sebagian besar wilayah selatan Kulon Progo. Uniknya lahan pasir ini tidak hanya berada di kawasan pantai saja, tetapi tersebar sampai sejauh 2000 meter dari garis pantai. Secara umum tanah pantai memiliki beberapa keunggulan di antaranya yaitu jumlah luas yang sangat besar. Lahan pasir pantai merupakan lahan marjinal yang memiliki produktivitas rendah.. Produktivitas lahan pasir pantai yang rendah disebabkan oleh faktor pembatas yang berupa kemampuan memegang dan menyimpan air rendah, infiltrasi dan evaporasi tinggi, kesuburan dan bahan organik sangat rendah dan efisiensi penggunaan air rendah (Kertonegoro, 2001; Al-Omran, et al., 2004). Produktivitas tanah dipengaruhi oleh kandungan C organik. KPK (Kapasitas Pertukaran Kation), tekstur tanah. Tanah pasir dicirikan bertekstur pasir, struktur berbutir, konsistensi lepas, sangat poros, sehingga daya sangga air dan hara sangat rendah (Pusat Penelitian Tanah dan Agroklimat, 1994), miskin hara dan kurang mendukung pertumbuhan tanaman. Tekstur tanah pasir ini sangat berpengaruh pada status dan distribusi air, sehingga berpengaruh pada sistem perakaran, kedalaman akar, hara dan pH (Syukur, 2005). Selanjutnya disebutkan bahwa lahan pasir pantai memiliki kemampuan menyediakan udara yang berlebihan, sehingga mempercepat pengeringan dan oksidasi bahan organik.

Bahan organik merupakan salah satu pembenah tanah yang telah dirasakan manfaatnya dalam perbaikan sifat-sifat tanah baik sifat fisik, kimia dan biologi tanah. Secara fisik memperbaiki struktur tanah, menentukan tingkat perkembangan struktur tanah dan berperan pada pembentukan agregat tanah (Tate, 1987 dalam Rajiman, dkk 2008), meningkatkan daya simpan lengas karena bahan organik mempunyai kapasitas menyimpan lengas yang tinggi (Stevenson, 1982 dalam Rajiman, dkk 2008). Menurut Mowidu (2001) pemberian 20-30 ton per hektar bahan organik berpengaruh nyata dalam meningkatkan porositas total, jumlah pori berguna, jumlah pori penyimpan lengas dan kemantapan agregat serta menurunkan kerapatann zarah, kerapatan bongkah dan permeabilitas. Low dan Piper ( 1973) dalam Sugito, dkk. (1995) menyatakan pemberian pupuk kandang sebanyak 75 ton per hektar pertahun selama 6 tahun berturut-turut dapat meningkatkan 4\% proporsi tanah, 14,5 $\%$ volume udara tanah pada keadaan kapasitas lapangan dan 33,3\% bahan organik serta menurunkan kepadatan tanah sebanyak $3 \%$.

Telah banyak penelitian pemanfaatan bahan organik untuk memperbaiki tanah pasir pantai, hasil penelitian Rajiman, dkk. (2008) menunjukkan bahwa dengan bahan organik dan limbah karbit 20 ton per hektar di tanah pasir pantai nyata meningkatkan jumlah fraksi lempung, debu, pori mikro, kadar lengas, menurunkan berat volume, berat jenis dan meningkatkan berat segar, berat kering, berat kering oven dan diameter umbi bawang merah dibanding kontrol. Hasil penelitian Wigati dkk. (2006) menunjukkan bahwa pemberian pupuk kandang ayam sampai 20 ton per hektar nyata meningkatkan kualitas tanah (kandungan bahan organik dan KPK). Hal ini berarti bahan organik tersebut mempunyai kemampuan yang lebih baik dan dapat dimanfaatkan sebagai perbaikan tanah pasir pantai Kulon Progo. Penelitian ini bertujuan untuk mengkaji manfaat bahan organik melalui penetapan berbagai jenis sumber bahan organik yang dapat memperbaiki beberapa sifat tanah pasir Pantai Selatan Kulon Progo. 


\section{BAHAN DAN METODE}

Penelitian ini dilaksanakan di Green House dan Laboratorium Tanah Fakultas Pertanian Universitas Muhammadiyah Yogyakarta. Tanah pasir pantai diambil dari Pantai Bugel, Kulon Progo, Yogyakarta. Alat penelitian: timbangan, gembor, label, polybag $35 \times 35 \mathrm{~cm}$, oven, botol timbang, kain kassa, gelas piala, statis, desikator, saringan plastik, cawan petri, botol semprot, piknometer, kawat pengaduk halus, termometer, tissue, ring, cepuk plastik, $\mathrm{pH}$ meter, karet pengikat, labu takar $50 \mathrm{ml}$, pipet $10 \mathrm{ml}$, gelas ukur, labu erlenmayer $50 \mathrm{ml}$, biuret, gelas arloji, piranti destruksi, piranti destilasi,dan tabung kjeldahl $250 \mathrm{ml}$. Bahan penelitian: tanah pasir pantai, kompos kotoran sapi, kompos kotoran ayam, kompos daun angsana (Pterocarpus indicus), kompos daun gamal (Gliricidia sepium), dan Bioaktivator.

Penelitian dilaksanakan dengan metode percobaan yang disusun dalam Rancangan Acak Lengkap (RAL) dengan 5 perlakuan. Perlakuan yang dimaksud adalah, (1) PO = Tanpa Kompos (Kontrol), (2) P1 = 30 ton per hektar kompos kotoran sapi, (3) P2 = 30 ton per hektar kompos kotoran ayam, (4) P3 = 30 ton per hektar kompos daun angsana, (5) P4 = 30 ton per hektar kompos daun gamal. Setiap perlakuan diulang 4 kali, sehingga menjadi 20 unit percobaan, ditambah dengan 5 polybag sebagai sampel yang digunakan untuk pengamatan mingguan sehingga diperoleh $20+5=25$ satuan percobaan.

Tahap penelitian yang dilakukan : (1) Pembuatan kompos (Pembuatan Kompos Kotoran Sapi dan Kotoran Ayam, Pembuatan Kompos Daun Gamal (Gliricidia sepium) dan Daun Angsana (Pterocarpus indicus) ) (2) Penyiapan Media dan Aplikasi Kompos (Pengambilan Tanah Pasir Pantai, Menghitung Kebutuhan Air Kapasitas Lapangan). Parameter yang diamati meliputi parameter sifat fisika dan kimia tanah pasir yang diamati yaitu kadar lengas tanah pasir seperti kadar lengas kering udara, kadar lengas kapasitas lapangan dan kadar lengas maksimum serta, porositas tanah, BJ, BV, pH tanah, kandungan BO, dan kandungan $\mathrm{N}$ yang diamati pada minggu ke 6. Data yang diperoleh dari masing - masing parameter disidik ragam (analysis of variance) dengan taraf kesalahan $\alpha=5 \%$.Jika terdapat beda nyata antar perlakuan dilakukan uji lanjutan dengan Uji Jarak Ganda Duncan dengan kesalahan $\alpha=5 \%$.

\section{HASIL DAN PEMBAHASAN}

Tanah merupakan medium tumbuh tanaman, serta secara biofisik dan biokemis medium tumbuh tersebut merupakan ruang interaksi tanah dan tanaman yang disebut rizosfer. Proses pertumbuhan dan perkembangan tanaman ditentukan oleh proses perolehan hara dan air oleh tanaman yang sebagian besar di dalam rizosfer (Gunawan, 2009).

Tanah pasiran merupakan tanah yang kandungan fraksi pasirnya dominan atau lebih besar 50 \% fraksi total. Gustafon (1962) dalam Rajiman, dkk. (2008) menyatakan bahwa secara umum tanah pasiran mempunyai tekstur kasar, agregatnya lemah sampai tak beragregasi, bersifat porus, kapasitas penyimpanan lengasnya rendah serta rentan terhadap erosi air dan angin. Salah satu upaya meningkatkan produktivitas lahan pasir pantai ini adalah mengelola ketersediaan hara dengan cara memasukkan berbagai bahan yang dapat memperbaiki sifat fisik dan menambah serta mempertahankan ketersediaan hara dalam tanah. Adapun beberapa hasil analisis kompos yang digunakan dalam penelitian adalah sebagai berikut: 
Tabel 1. Hasil Analisis Kandungan Kimia dalam Kompos

\begin{tabular}{lccccc}
\hline \multicolumn{1}{c}{ Kompos } & KL (\%) & C-Organik (\%) & BO (\%) & N (\%) & C/N \\
\hline Sapi & 35,33 & 4,218 & 7,27 & 1,55 & 2,721 \\
Ayam & 44,34 & 4,251 & 7,33 & 1,49 & 2,853 \\
Daun Gamal & 48,27 & 19,063 & 32,87 & 2,61 & 7,303 \\
Daun Angsana & 58,33 & 18,630 & 32,12 & 2,60 & 7,175 \\
\hline
\end{tabular}

Berdasarkan hasil analisis kimia kompos, dapat diketahui bahwa kompos daun Angsana memiliki kandungan kimia yang lebih besar dari pada kompos sapi, ayam, dan gamal. Aplikasi kompos dari berbagai bahan organik dilakukan untuk memperbaiki sifat tanah pasir pantai, sehingga bisa dimanfaatkan sebagai lahan pertanian yang lebih produktif. Hasil penelitian tentang pengaruh bahan organic terhadap sifat tanah adalah sebagai berikut:

\section{Pengaruh Kompos dari berbagai Bahan Organik terha-} dap Kelengasan Tanah Pasir Pantai

Lengas tanah adalah air yang mengisi sebagian atau seluruh ruang pori tanah dan teradsorpsi pada permukaan zarah tanah. Lengas tanah juga dapat diartikan sebagai air yang terdapat dalam tanah yang terikat oleh berbagai kakas, yaitu kakas ikat matrik, osmosis, dan kapiler. Apabila kandungan lengas tanah terus berkurang, sehingga tidak mampu mengimbangi kehilangan air akibat evapotranspirasi maka tanah dikatakan dalam keadaan titik layu tetap (permanent wilting point).

Tabel 2. Kelengasan Tanah Pasir Pantai yang Diperlakukan dengan berbagai Kompos

\begin{tabular}{lccc}
\hline Perlakuan Kompos & $\begin{array}{c}\text { Kadar Lengas Kering } \\
\text { Angin (\%) }\end{array}$ & $\begin{array}{c}\text { Kadar Lengas Kap. } \\
\text { Lapangan (\%) }\end{array}$ & $\begin{array}{c}\text { Kadar Lengas } \\
\text { Maksimum (\%) }\end{array}$ \\
\hline Kontrol (P0) & $0,12 \mathrm{c}$ & $10,02 \mathrm{~b}$ & $22,99 \mathrm{~d}$ \\
Sapi (P1) & $0,18 \mathrm{ab}$ & $14,68 \mathrm{a}$ & $25,16 \mathrm{~b}$ \\
Ayam (P2) & $0,15 \mathrm{~b}$ & $14,30 \mathrm{a}$ & $24,44 \mathrm{c}$ \\
Daun Gamal (P3) & $0,18 \mathrm{ab}$ & $14,97 \mathrm{a}$ & $25,62 \mathrm{~b}$ \\
Daun Angsana (P4) & $0,20 \mathrm{a}$ & $15,24 \mathrm{a}$ & $26,30 \mathrm{a}$ \\
\hline
\end{tabular}

Keterangan: Angka yang diikuti dengan huruf yang sama menunjukkan tidak berbeda nyata pada uji Duncan $5 \%$.
Berdasarkan tabel 2, dapat dijelaskan bahwa pengaruh perlakuan kompos P1, P2, P3, dan $\mathrm{P} 4$ berbeda nyata dengan pengaruh perlakuan tanpa kompos (P0) dalam meningkatkan kadar lengas tanah yaitu kadar lengas kering angin, kadar lengas kapasitas lapangan dan kadar lengas maksimum tanah. Pengaruh perlakuan P4 tidak berbeda nyata dengan pengaruh perlakuan P1 dan P3 tetapi berbeda nyata dengan pengaruh perlakuan P0 dan P2 dalam meningkatkan kadar lengas kering angin tanah pasir pantai. Sedangkan pengaruh perlakuan P1, P2, dan P3 tidak berbeda nyata tetatpi berbeda nyata dengan pengaru perlakuan PO dalam meningkatkan kadar lengas kering angin tanah pasir.

Pengaruh perlakuan P4 tidak berbeda nyata dengan pengaruh perlakuan $\mathrm{P} 1, \mathrm{P} 2$, dan $\mathrm{P} 3$, tetapi berbeda nyata dengan pengaruh perlakuan P0 dalam meningkatkan kadar lengas kapasitas lapangan tanah pasir pantai. Sedangkan dalam meningkatkan kadar lengas maksimum tanah, pengaruh perlakuan P4 berbeda nyata dengan perlakuan P0, P1, P2, dan P3. Pada pengaruh perlakuan P3 berbeda nyata dengan P0, P2, dan P4 tetapi tidak berbeda nyata dengan pengaruh perlakuan $\mathrm{P} 1$, sedangkan pengaruh perlakuan P2 berbeda nyata dengan perlakuan P0, P1, P3, dan P4 dalam meningkatkan kadar lengas maksimum tanah pasir pantai.

Pada perlakuan P4 menghasilkan nilai rerata tertinggi dalam meningkatkan berbagai kelengasan tanah pasir pantai dibandingkan sampel tanah pasir yang diperlakukan dengan P0, P1, P2, dan P3 (Tabel 2).Hal ini menunjukkan bahwa kemampuan tanah dalam menahan air pada perlakuan P4 lebih baik dibandingkan dengan perlakuan lainnya. Kemampuan menyimpan air pada tanah ditentukan oleh porositas dan kandungan bahan organik yang ada pada tanah tersebut. Porositas total tanah yang tinggi 
akan menyimpan air yang lebih tinggi. Bahan organik tanah juga berperan terhadap ketersediaan air di dalam tanah, karena bahan organik dapat memegang air dengan baik serta dapat meningkatkan porositas total tanah. Oleh karena itu, dengan memiliki porositas total tanah dan bahan organik tanah yang lebih tinggi maka perlakuan P4 memiliki air tersedia lebih tinggi dibandingkan perlakuan lainnya. Pemberian bahan organik berupa kompos akan membentuk ruang pori mikro menjadi lebih banyak, dimana pori mikro merupakan pori yang digunakan tanah untuk mengikat air. Semakin banyak ruang pori mikro yang terbentuk maka tanah akan mempunyai daya simpan lengas yang semakin meningkat, lengas tanah akan mengisi ruang pori-pori tanah, biasannya ruang pori tanah yang terisi adalah pori-pori besar, terlebih dahulu baru mengisi pori-pori mikro. Jika terjadi penguapan atau penggunaan air oleh tanaman maka poripori besar dahulu yang ditinggalkan oleh air lalu menyusul pori-pori mikro.

Bahan organik yang telah mengalami pelapukan mempunyai kemampuan yang cukup tinggi untuk menyimpan air karena bersifat hidrofilik, sehingga dapat terjadi peningkatan pori air tersedia (Stevenson, 1997 dalam Gunawan 2009). Arsyad (2000) dalam Wijayanti (2008) menyatakan bahwa bahan organik yang telah melapuk mempunyai kemampuan menyerap air yang tinggi. Serapan air oleh bahan organik mencapai dua sampai tiga kali bobot bahan organik tersebut. Lebih lanjut Soepardi (1983) dalam Wijayanti (2008) menyatakan bahwa pori air tersedia sangat menentukan nilai kadar air. Semakin tinggi nilai pori air tersedia akan meningkatkan kadar air tanah. Tanah yang mempunyai pori berukuran kecil dan sedang yang tinggi akan cenderung menahan air lebih kuat dibandingkan tanah yang mempunyai banyak pori berukuran besar.
Selain itu Syukur (2005) menyebutkan bahwa peran bahan organik dengan hasil dekomposisi berupa humus dapat meningkatkan kesuburan fisik tanah. Humus mempunyai luas permukaan dan kemampuan menyerap air yang lebih besar dari lempung.

Muslimin, dkk. (2012) menyatakan bahwa bahan organik tanah mempunyai pori-pori yang jauh lebih banyak daripada partikel mineral tanah yang berarti luas permukaan penyerapan juga lebih banyak, sehingga makin tinggi kadar bahan organik tanah makin tinggi kadar dan ketersediaan air tanah. Tanah yang mempunyai ruang pori lebih banyak akan mampu menyimpan air dalam jumlah lebih banyak. Karena ruangruang pori tanah akan terisi oleh air dan pada akhirnya akan memiliki kelengasan tanah yang lebih tinggi dari semua kelengasan tanah, baik kadar lengas kering angin, kadar lengas kapasitas lapangan dan kadar lengas maksimum.

Pengaruh Kompos dari berbagai Bahan Organik Terhadap BV, BJ dan Porositas Tanah

Hasil sidik ragam terhadap berat volume tanah, porositas tanah total menunjukkan bahwa dengan perlakuan kompos (P1, P2, P3, dan P4) berpengaruh nyata untuk memperbaiki BV dan Porositas tanah pasir dalam membentuk ruang pori pada tanah, tetapi perlakuan kompos (P1, P2, P3, dan P4) tidak berpengaruh nyata dalam memperbaiki BJ tanah pasir pantai.

Tabel 3. BV, BJ dan Porositas Total Tanah Pasir Pantai yang Diperlakukan dengan berbagai Kompos

\begin{tabular}{lccc}
\hline Perlakuan Kompos & $\mathrm{BV}\left(\mathrm{g} / \mathrm{cm}^{3}\right)$ & $\mathrm{BJ}\left(\mathrm{g} / \mathrm{cm}^{3}\right)$ & $\begin{array}{c}\text { Porositas Tanah } \\
\text { Total }(\%)\end{array}$ \\
\hline Kontrol (P0) & $2,09 \mathrm{a}$ & $3,34 \mathrm{a}$ & $37,19 \mathrm{~b}$ \\
Sapi (P1) & $1,99 \mathrm{~b}$ & $3,30 \mathrm{a}$ & $39,41 \mathrm{ab}$ \\
Ayam (P2) & $1,99 \mathrm{~b}$ & $3,30 \mathrm{a}$ & $39,74 \mathrm{ab}$ \\
Daun Gamal (P3) & $1,96 \mathrm{~b}$ & $3,30 \mathrm{a}$ & $40,39 \mathrm{ab}$ \\
Daun Angsana (P4) & $1,92 \mathrm{c}$ & $3,30 \mathrm{a}$ & $41,79 \mathrm{a}$ \\
\hline Keterangan: Angka yang diikuti dengan huruf yang sama menunjukkan tidak berbeda nyata
\end{tabular}
pada uji Duncan $5 \%$. 
Tabel 3, dapat diketahui bahwa pengaruh perlakuan P1, P2, P3 dan P4 berbeda nyata dengan pengaruh perlakuan PO dalam memperbaiki BV tanah pasir pantai. Pengaruh Perlakuan P4 tidak berbeda nyata dengan pengaruh perlakuan P3, tetapi berbeda nyata dengan pengaruh perlakuan P0, P1, dan P2. Berdasarkan tabel 3, diketahui bahwa pengaruh perlakuan $\mathrm{P} 4$ tidak berbeda nyata dengan perlakuan P1, P2, dan P3 tapi berbeda nyata dengan PO dalam memperbaiki porositas tanah pasir.

Pemberian kompos yang dicobakan dapat menurunkan berat volume dan meningkatkan total porositas pada tanah pasir pantai. Berat volume terendah dan total porositas tanah tertinggi dijumpai pada pengaruh perlakuan P4. Secara umum nilai rerata berat volume perlakuan kompos semakin rendah. Tanah yang memiliki berat volume yang rendah menghasilkan bahan organik yang tinggi dan ruang pori mikro tanah juga tinggi. Tingginya ruang pori mikro tanah dapat meningkatkan kemampuan tanah dalam mengikat lengas tanah. Hal ini dikarenakan adanya sumbangan C-organik sebagai sumber bahan organik tanah yang lebih tinggi dibandingkan dengan perlakuan lainnya sehingga terjadi penurunan berat volume dan peningkatan total porositas lebih baik dibandingkan dengan berat volume dan total porositas pada perlakuan lainnya. Peningkatan C-organik dibuktikan dari pengamatan parameter C-organik (Tabel 5). Endriani, dkk (2003) yang menyatakan bahwa semakin tinggi bahan organik tanah menyebabkan berat volume semakin rendah dan total porositas semakin tinggi sehingga kemampuan dalam menyimpan lengas tinggi.

Pemberian kompos P4 mampu memberikan sumbangan terhadap peningkatan ketersediaan C-organik tanah. Peningkatan C-organik tidak terlepas dari peranan kompos yang mampu mem- berikan sumbangan bahan organik dan mampu mempercepat proses perombakan bahan organik menjadi humus dalam tanah sehingga mampu menurunkan berat volume tanah dan meningkatkan total porositas tanah. Hasil perombakan bahan organik ini akan membuat tanah lebih gembur, memperbaiki aerasi tanah dan struktur tanah, berat volume dan total porositas tanah yang selanjutnya ketersediaan hara menjadi lebih baik.

Pemberian kompos P4 mempunyai sifat mampu menurunkan berat volume tanah yang padat menjadi serang (porous) akibat bertambahnya total porositas tanah serta meningkatkan kandungan bahan organik tanah pada tanah pasir pantai. Bahan organik tanah memiliki peran dan fungsi yang sangat vital di dalam perbaikan sifat-sifat tanah, meliputi sifat fisika, kimia dan biologi tanah.Bahan organik merupakan sumber energi bagi aktivitas mikrobia tanah dan dapat memperbaiki berat volume tanah, struktur tanah, aerasi serta daya mengikatair.Hal ini sesuai dengan pendapat Wolf and Synder (2003) dalam Sulistyowati (2007), bahwa porositas dipengaruhi oleh bahan organik tanah. Makin tinggi bahan organik tanah akan semakin rendah bobot volume tanah dan semakin tinggi total ruang pori tanah.Hal ini sesuai dengan hasil penelitian yang dilakukan oleh Chusnul (2007), dengan pemberian kompos sampah kampus dapat menurunkan berat volume tanah entisol dari 1,34 menjadi 1,12\%. Berdasarkan penelitian Endiani, dkk. (2000) dalam Baharudin (2005), diketahui bahwa pemberian pupuk bokashi selain mampu menurukan berat volume tanah juga mampu memperbaiki porositas total tanah pada pemberian 10 ton per hektar dari 56,95\% menjadi 65,91\%. Muslimin, dkk. (2012) juga menyatakan bahwa tanah dengan bahan organik yang tinggi mempunyai berat volume relatif rendah. Tanah 
dengan pori total tinggi, seperti tanah lempung, cenderung mempunyai berat volume lebih rendah. Sebaliknya, tanah dengan tekstur kasar, walaupun ukuran porinya lebih besar, namun total porinya lebih kecil, mempunyai berat volume yang lebih tinggi.

Berdasarkan tabel 3, dapat dilihat bahwa pengaruh perlakuan kompos (P1, P2, P3 dan P4) tidak berbeda nyata dengan pengaruh perlakuan tidak diberikan kompos (P0) dalam memperbaiki berat jenis tanah pasir pantai.Hal ini dikarenakan berat jenis tanah lebih dipengaruhi olehmineral-mineral penyusun tanah sehingga memerlukan waktu yang cukup lama. Berat jenis tanah merupakan perbandingan antara massa padatan dengan volume padatan dari suatu tanah. Berat jenis dari suatu tanah menunjukkan kerapatan dari partikel padat secara keseluruhan. Hal ini sependapat dengan Kohke (1968) dalam Maulana, dkk. (2013) yang mengemukakan bahwa berat jenis tanah dipengaruhi oleh oleh jenis mineral yang menyusun tanahnya.

\section{Pengaruh Kompos dari berbagai Bahan Organik Terha- dap $\mathrm{pH}$ Tanah}

Reaksi tanah menunjukkan sifat kemasaman atau alkalinitas tanah yang dinyatakan dengan nilai $\mathrm{pH}$.Nilai $\mathrm{pH}$ menunjukkan banyaknya konsentrasi ion hidrogen $(\mathrm{H}+)$ di dalam tanah. Makin tinggi kadar ion $\mathrm{H}+$ dalam tanah, semakin masam tanah tersebut. Di dalam tanah selain ion $\mathrm{H}+$ dan ion-ion lain ditemukan pula ion $\mathrm{OH}$-yang jumlahnya berbanding terbalik dengan banyaknya $\mathrm{H}+$. Pada tanah-tanah yang masam jumlah ion $\mathrm{H}+$ lebih tinggi dibanding $\mathrm{OH}$-, sedang pada tanah alkalin kandungan $\mathrm{OH}$ - lebih banyak daripada $\mathrm{H}+$. Bila kandungan $\mathrm{H}^{+}$sama dengan $\mathrm{OH}$ - maka tanah bereaksi netral yaitu mempunyai $\mathrm{pH}=7$. Konsentrasi $\mathrm{H}+$ atau $\mathrm{OH}$ dalam tanah sebenarnya sangat kecil. Nilai $\mathrm{pH}$ berkisar antara 0-14 dengan $\mathrm{pH} 7$ disebut netral sedang $\mathrm{pH}$ kurang dari 7 disebut masam dan $\mathrm{pH}$ lebih dari 7 disebut alkalis.

Tabel 4. $\mathrm{pH}_{2} \mathrm{O}$ Tanah Pasir yang Diperlakukan dengan berbagai Kompos

\begin{tabular}{ll}
\hline \multicolumn{1}{c}{ Perlakuan Kompos } & $\mathrm{pH}$ \\
\hline Kontrol (P0) & $6,25 \mathrm{~b}$ \\
Sapi (P1) & $6,75 \mathrm{a}$ \\
Ayam (P2) & $7,00 \mathrm{a}$ \\
Daun Gamal (P3) & $7,00 \mathrm{a}$ \\
Daun Angsana (P4) & $7,00 \mathrm{a}$ \\
\hline
\end{tabular}

Keterangan: Angka yang diikuti dengan huruf yang sama menunjukkan tidak berbeda nyata pada uji Duncan $5 \%$.

Pada tabel 4, menunjukkan bahwa pengaruh perlakuan P0 berbeda nyata dengan pengaruh perlakuan P1, P2, P3, dan P4, sedangkan pengaruh perlakuan kompos P1, P2, P3, dan P4 tidak berbeda nyata terhadap $\mathrm{pH}$ tanah pasir pantai. Hasil penelitian ini menunjukkan bahwa perlakuan kompos dapat meningkatkan $\mathrm{pH}$ tanah pasir pantai (Tabel 4). Peningkatan $\mathrm{pH}$ disebabkan adanyaproses perombakan dari berbagai jenis bahan organik berupa kompos yang telah diberikan ke dalam tanah pasir pantai.Hasil perombakan tersebut akan menghasilkan kationkation basa yang mampu meningkatkan $\mathrm{pH}$. Penambahan bahan organik pada tanah masam, antara lain entisol, ultisol dan andisol mampu meningkatkan $\mathrm{pH}$ tanah dan mampu menurunkan Al tertukar tanah (Suntoro, 2003). Penelitian Nugraheni (2006) menyatakan bahwa pemberian $50 \%$ limbah tapioka dan 50\% kotoran ayam (dosis 20 ton per hektar) dapat meningkatkan $\mathrm{pH}$ tanah dari 6 menjadi 7,42. Senada dengan hal tersebut, dalam penelitian ini kenaikan $\mathrm{pH}$ diduga karena pelepasan kation-kation basa dari bahan organik yaitu dari kompos ke dalam tanah sehingga tanah jenuh dengan kation-kation basa. Supartini (1975) dalam Wijayanti (2008) mengemukakan bahwa proses pelapukan akan membebaskan kation basa yang menyebabkan $\mathrm{pH}$ tanah meningkat. 
Pengaruh Bahan Organik Terhadap C- Organik, Kadar Bahan Organik Tanah, N Total Tanah dan Rasio C/N

Hasil sidik ragam menunjukkan bahwa dengan perlakuan kompos P1, P2, P3, dan P4 berpengaruh nyata dalam meningkatkan $\mathrm{C}$ Organik, bahan organik tanah dan $\mathrm{N}$ total pasir pantai serta menurunkan rasio $\mathrm{C} / \mathrm{N}$. Tabel 5 , menunjukkan bahwa Perlakuan P4, menghasilkan C-Organik yang paling tinggi dibandingkan dengan sampel tanah pasir pantai yang diperlakukan dengan P0, P1, P2, dan P3. Terjadinya peningkatan kandungan C-Organik tanah ini, karena kompos yang digunakan merupakan salah satu sumber utama dari bahan organik. Bahan organik adalah merupakan setiap bahan yang berasal dari sisa-sisa tanaman atau hewan yang dapat diberikan diatas atau dalam permukaan tanah yang dapat menambah kandungan C-Organik dan unsur hara tanah. Hal ini sesuai dengan hasil penelitian Syukur dan Indah (2006) dalam Wijayanti (2008), bahwa aplikasi kompos dan pupuk kandang dapat meningkatkan kandungan C-Organik tanah. Semakin banyak bahan organik yang ditambahkan ke dalam tanah, semakin besar peningkatan kandungan C-Organik dalam tanah.

Tabel 5. C-Organik, BO, N dan Rasio C/N Tanah Pasir yang Diperlakukan dengan berbagai Kompos

\begin{tabular}{lcccc}
\hline \multicolumn{1}{c}{ Perlakuan } & C- Organik (\%) & BO (\%) & N (\%) & Rasio C/N \\
\hline Kontrol (P0) & $0,25 \mathrm{c}$ & $0,42 \mathrm{c}$ & $0,011 \mathrm{~b}$ & $21,87 \mathrm{a}$ \\
Sapi (P1) & $0,30 \mathrm{c}$ & $0,51 \mathrm{c}$ & $0,250 \mathrm{a}$ & $1,208 \mathrm{~b}$ \\
Ayam (P2) & $0,34 \mathrm{c}$ & $0,59 \mathrm{c}$ & $0,240 \mathrm{a}$ & $1,389 \mathrm{~b}$ \\
Daun Gamal (P3) & $0,59 \mathrm{~b}$ & $1,01 \mathrm{~b}$ & $0,250 \mathrm{a}$ & $2,389 \mathrm{~b}$ \\
Daun Angsana (P4) & $0,83 \mathrm{a}$ & $1,43 \mathrm{a}$ & $0,220 \mathrm{a}$ & $3,899 \mathrm{~b}$ \\
\hline
\end{tabular}

Keterangan: Angka yang diikuti dengan huruf yang sama menunjukkan tidak berbeda nyata pada uji Duncan 5\%.

Berdasarkan tabel 5, menunjukkan bahwa pengaruh perlakuan P3 dan P4 berbeda nyata dengan pengaruh perlakuan P0, P1 dan P2, sedangkan untuk pengaruh perlakuan P1 dan
P2 tidak berbeda nyata dengan pengaruh perlakuan P0 dalam meningkatkan kandungan bahan organik tanah pasir pantai. Kandungan bahan organik tanah yang tertinggi terdapat pada perlakuan P4 dibandingkan perlakuan kompos lainnya. Hal ini disebabkan karena kompos yang diberikan kedalam tanah pasir termasuk salah satu sumber BO tanah. Peningkatan BO tanah bukan saja akibat penambahan $\mathrm{BO}$ dalam bentuk kompos, tetapi dimungkinkan juga dipengaruhi faktor lain, seperti tingginya kadar lengas tanah, BV dan porositas tanah.

Bakri (2001) berpendapat bahwa penambahan bahan organik ke dalam tanah akan menjadikan ikatan antar partikel bertambah kuat dengan meningkatnya kadar bahan organik tanah. Menurut Louwim (2008) dalam Bakri (2001), bahan organik sangat berpengaruh dalam mempengaruhi sifat fisik tanah diantaranya memperbaiki struktur tanah, meningkatkan agregat tanah dan meningkatkan pertumbuhan tanaman.

Kandungan nitrogen total tanah menggambarkan kandungan nitrogen baik dalam bentuk nitrogen organik maupun an-organik. Penetapan kandungan nitrogen total tanah dilakukan terhadap sampel tanah dari setiap perlakuan setelah 6 minggu masa inkubasi. Berdasakan tabel 5, menunjukkan bahwa pengaruh perlakuan kompos (P1, P2, P3, dan P4) berbeda nyata dengan pengaruh perlakuan tanpa kompos (P0) terhadap kadar $\mathrm{N}$ total tanah pasir. Namun kadar $\mathrm{N}$ total pada setiap semua pengaruh perlakuan kompos tidak berbeda nyata. Pemberian bahan organik dari sumber berbagai kompos berpengaruh nyata dalam meningkatkan $\mathrm{N}$ total dibandingkan dengan tanpa pemberian bahan organik. Pembenaman dalam proses inkubasi sangat membantu mikroorganisme merombakbahan organik, laju dekomposisinyameningkat sehingga mineralisasi nitrogen berjalan lebih cepat. Rasio $\mathrm{C} / \mathrm{N}$ di- 
pengaruhi kadar $\mathrm{N}$ total, semakin besar $\mathrm{N}$ total tanah maka rasio $\mathrm{C} / \mathrm{N}$ yang dihasilkan semakin rendah. Hal ini ditemui pada kompos yang lebih besar $\mathrm{N}$ totalnya dibandingkan dengan tanpa kompos. Peran bahan organik terhadap ketersediaan hara dalam tanah tidak terlepas dengan proses mineralisasi yang merupakan tahap akhir dari proses perombakan bahan organik. Menurut pendapat Munawar (2011), bahan organik yang terdapat dalam kompos mengalami proses mineralisasi $\mathrm{N}$ organik menjadi $\mathrm{NH} 4+$ dan $\mathrm{NO} 3$ sehingga nitrogen akan lebih banyak terbentuk dan tersedia di dalam tanah.

Berdasarkan Tabel 5, menunjukkan bahwa pengaruh perlakuan P1, P2, P3, dan P4 berbeda nyata dengan perlakuan $\mathrm{PO}$ dalam memperbaiki rasio $\mathrm{C} / \mathrm{N}$ tanah. Tetapi perlakuan $\mathrm{P} 1, \mathrm{P} 2, \mathrm{P}$, dan $\mathrm{P} 4$ tidak berbeda nyata dalam memperbaiki rasio $\mathrm{C} / \mathrm{N}$ tanah pasir pantai. Perlakuan $\mathrm{PO}$ memiliki nilai rasio $\mathrm{C} / \mathrm{N}$ tertinggi dibandingkan dengan perlakuan lainnya. Kadar N dan C mempengaruhi rasio $\mathrm{C} / \mathrm{N}$. Hal ini dikarenakan perlakuan PO dipengaruhi oleh mineral - mineral pada pasir pantai dan memiliki kandungan $\mathrm{N}$ dan $\mathrm{C}$ yang sangat rendah. Pada perlakuan kompos, kompos dari kotoran hewan memiliki nilai rasio $\mathrm{C} / \mathrm{N}$ terendah di bandingkan kompos dari tanaman. Hal ini karena dipengaruh kandungan serat yang ada didalam bahan organik yang telah diberikan. Kandungan serat pada kotoran hewan yaitu 12,52 - $15 \%$, sedangkan pada pada daun yaitu $14 \%$ - 30 \% (Putri, 2010). Jika bahan organik mempunyai kandungan lignin tinggi kecepatan mineralisasi Nakan terhambat dan rasio C/N akan tinggi. Menurut Hakim et al. (1986), suatu dekomposisi bahan organik yang lanjut dicirikan dengan rasio $\mathrm{C} / \mathrm{N}$ yang rendah. Sedangkan rasio $\mathrm{C} / \mathrm{N}$ yang tinggi menunjukkan bahwa dekomposisi belum berlanjut atau baru dimulai. Dalam proses tersebut terjadi penurunan karbon dan peningkatan nitrogen (Brady, 1990 dalam Wijayanti, 2008).

\section{SIMPULAN}

Pemberian kompos kotoran sapi (P1), kotoran ayam (P2), daun gamal (P3) dan daun angsana (P4) dapat memperbaiki sifat fisik tanah (Kelengasan tanah, porositas tanah, dan berat volume) dan sifat kimia tanah ( $\mathrm{pH}$ tanah, C-organik tanah dan Bahan organik tanah). Namun pemberian kompos daun angsana memberikan pengaruh yang terbaik dalam memperbaiki beberapa sifat fisik dan kimia tanah seperti kadar lengas, berat volume tanah, dan porositas tanah dan COrganik tanah.

Penelitian ini akan lebih baik jika diaplikasikan oleh tanaman agar dapat mengetahui pengaruh pertumbuhan tanaman ditanah pasir pantai dan perlu penambahan waktu dan dosis untuk melihat perubahan beberapa sifat fisik dan kimia tanah pasir.

\section{DAFTAR PUSTAKA}

Baharudin \& Djafar M. 2005. Kajian Penggunaan Bahan Organik DalamPeningkatan Produktivitas Lahan Dan Tanaman Di Daerah BeriklimKering. Soil Environment Vol 3 No 2: 41-51

Bakri. 2001. Pengaruh Lindi Dan Kompos Sampah Kota Terhadap Beberapa Sifatlnceptisol Dan Hasil Jagung (Zea mays. L). Agrista Volume 5 No 2: 114 -119

Chusnul_Agustina, 2007. Pengaruh Pemberian KomposTerhadap Beberapa Sifat Fisik EntisolSerta Pertumbuhan Tanaman Jagung (Zea Mays L). S1 Skripsi. Fakultas PertanianJurusan TanahProgram Studi Ilmu Tanah. Universitas Brawijaya. Malang

Endriani, Zurhalena dan Refliaty. 2003. Perbaikan sifat fisika tanah Ultisol dan hasil tanamanmelalui pemberian pupuk bokashi. Prosiding Buku I. Kongres Nasional VIII Himpunanllmu Tanah Indonesia. Padang, 21-23 Juli 2003.

ES. Wigati, Abdul Syukur, dan Bambang DK, 2006. Pengaruh Takaran Bahan Organik Dan TingkatKelengasan Tanah Terhadap Serapan FosforOleh Kacang Tunggak Di Tanah Pasir Pantai. Jurnal Ilmu Tanah dan Lingkungan Vol 6 (1) (2006) p: $52-58$

Gloria, S. 2013. Panjang Garis Pantai Indonesia. http://nationalgeographic.co.id/ berita/2013/10/terbaru-panjang-garis-pantai-Indonesia-capai-99000-kilometer. Diakses 5 Maret 2014 
Gunawan_Budiyanto. 2009, Bahan Organik Dan Pengelolaan Nitrogen Lahan Pasir, Unpad Press. Bandung.

Hakim, N., M. Y. Nyakpa, A. M. Lubis, S. G. Nugroho, M. A. Diha, Go Bang Hodan H. H. Baily. 1986. Dasar- dasar Ilmu Tanah. Universitas Lampung. Lampung.

Kertonegoro, B. D. 2001. Gumuk Pasir Pantai Di D.I. Yogyakarta : Potensi dan Pemanfaatannya untuk Pertanian Berkelanjutan. Prosiding Seminar Nasional Pemanfaatan Sumberdaya Lokal Untuk Pembangunan Pertanian Berkelanjutan.Universitas Wangsa Manggala pada tanggal 02 Oktober 2001. h 46-54.

Maulana, Z. Budi, P., Soemarno. 2013, Pengaruh Kompos, Pupuk Kandang, dan Custom-Bio terhadap Sifat Tanah , Pertumbuhan dan Hasil Tebu (Saccharum officinarum L.) pada Entisol di Kebun Ngrangkah-Pawon, Kediri. Indonesian Green Technology Journal. E-ISSN.2338-1787

Mowidu, 1.2001.Peranan Bahan Organik dan Lempung Terhadap Agregasi dan Agihan Ukuran Pori pada Entisol. Tesis Pasca Sarjana. Universitas Gadjah Mada. Yogyakarta.

Munawar, A. 2011.Kesuburan Tanah dan Nutrisi Tanaman. PT. Penerbit IPB Press, Bogor.

Muslimin, M. Asmita, A. Anshor, M. dan Masyur, S. 2012. Dasar Dasar Ilmu Tanah,Program Studi Agroteknologi, Jurusan llmu Tanah,Fakultas Pertanian Universitas Hasanuddin.Makassar

Nugraheni, A. 2006. Kaji Banding Kombinasi Bahan Kompos LimbahPadat Tapioka, Sampah Organik dan Kotoran Ayam TerhadapMineralisasi N Pada Tanah Entisol Wajak, Malang. Skripsi Jurusan TanahFakultas Pertanian Universitas Brawijaya. Malang.

Pusat Penelitian Tanah dan Agroklimat, 1994.Survei Tanah Detail di Sebagian Wilayah D.I. Yogyakarta (skala 1 : 50.000). Proyek LREP II Part C. Puslittanak. Bogor

Putri.A.F, 2010. Seleksi Serasah Tanaman Koleksi Kebun Raya Purwodadi Dalam Upaya Menghasilkan Kompos Berkualitas Tinggi. Seminar Nasional Biologi. Upt Bkt Kebun Raya Purwodadi. Purwodadi

Rajiman, Prapto_Yudono, Endang_Sulistyaningsih, dan Eko_Hanudin, 2008. Pengaruh Pembenah Tanah Terhadap Sifat Fisika TanahDan Hasil Bawang Merah Pada Lahan Pasir Pantai BugelKabupaten Kulon Progo. Agrin Vol. 12, No. 1, April 2008. ISSN: 1410-0029

Sugito, Y., Yulia N, dan Ellis N. 1995. Sistem Pertanian Organik. Fakultas PertanianUniversitas Brawijaya. Malang. 83p.

Sulistyowati, E. 2007. Pengaruh Pemberian Kompos Enceng Gondok (Eichhorniacrassipes (Mart) Solms) Dan Pupuk Kandang Sapi Terhadap AgregasiTanah Dan Pertumbuhan Tanaman Jagung (Zea mays L) Pada Alfisol,Pagak Malang Selatan. Skripsi jurusan Tanah Fakultas PertanianUniversitas Brawijaya. Malang.

Suntoro, W.A. 2003. Peranan Bahan Organik TerhadapKesuburan Tanah Dan UpayaPengelolaannya. Pidato Pengukuhan Guru Besar, Ilmu Kesuburan Tanah, Fakultas Pertanian. Universitas Sebelas Maret. Solo

Syukur, A. 2005.Pengaruh Pemberian Bahan Organik Terhadap Sifat-Sifat Tanah dan Pertumbuhan Caisin di Tanah Pasir Pantai. J. IImu Tanah dan Lingkungan 5 (1) : 30-38.
Syukur, A dan N. M. Indah. 2006. Kajian Pengaruh Pemberian Macam PupukOrganik Terhadap Pertumbuhan Dan Hasil Tanaman Jahe Di InceptisolKaranganyar. Jurnal Ilmu Tanah Dan Lingkungan Vol 6 (2) : 124-131

Wijayanti, H. 2008. Pengaruh Pemberian Kompos Limbah PadatTempe Terhadap Sifat Fisik, Kimia Tanah DanPertumbuhan Tanaman Jagung (Zea Mays) Serta Efisiensi Terhadap Pupuk Urea Pada EntisolWajak-Malang. SkripsiFakultas Pertanianjurusan Tanah Program Studi Ilmu Tanah, Universitas Brawijaya. Malang 